Article

\title{
Inorganic Anions Regulate the Phase Transition in Two Organic Cation Salts Containing [(4-Nitroanilinium)(18-crown-6)] $]^{+}$Supramolecules
}

\author{
Yuan Chen, Yang Liu *, Binzu Gao, Chunli Zhu and Zunqi Liu * \\ Chemical Engineering College, Xinjiang Agricultural University, Urumqi 830052, China; \\ chenyuanxj90@163.com (Y.C.); xjdgbz2001@163.com (B.G.); zhuchunlixj90@163.com (C.Z.) \\ * Correspondence: liuyangxj85@163.com (Y.L.); lzq@xjau.edu.cn (Z.L.); Tel.: +86-991-876-2834 (Z.L.) \\ Academic Editor: Anna Painelli \\ Received: 28 May 2017; Accepted: 6 July 2017; Published: 15 July 2017
}

\begin{abstract}
Two novel inorganic-organic hybrid supramolecular assemblies, namely, (4-HNA) (18-crown-6) $\left(\mathrm{HSO}_{4}\right)(\mathbf{1})$ and (4-HNA $)_{2}(18 \text {-crown-6) })_{2}\left(\mathrm{PF}_{6}\right)_{2}\left(\mathrm{CH}_{3} \mathrm{OH}\right)(2)$ (4-HNA = 4-nitroanilinium), were synthesized and characterized by infrared spectroscopy, single $\mathrm{X}$-ray diffraction, differential scanning calorimetry (DSC), and temperature-dependent dielectric measurements. The two compounds underwent reversible phase transitions at about $255 \mathrm{~K}$ and $265 \mathrm{~K}$, respectively. These phase transitions were revealed and confirmed by the thermal anomalies in DSC measurements and abrupt dielectric anomalies during heating. The phase transition may have originated from the [(4-HNA)(18-crown-6)] $]^{+}$supramolecular cation. The inorganic anions tuned the crystal packings, and thus influenced the phase-transition points and types. The variable-temperature $\mathrm{X}$-ray diffraction data for crystal 1 revealed the occurrence of a phase transition in the high-temperature phase with the space group of $P 2_{1} / \mathrm{c}$ and in the low-temperature phase with the space group of $P 2_{1} / \mathrm{n}$. Crystal 2 exhibited the same space group $P 2_{1} / \mathrm{c}$ at different temperatures. The results indicated that crystals 1 and 2 both underwent an iso-structural phase transition.
\end{abstract}

Keywords: phase transition; crystal structure; dielectric anomaly; supramolecular cation; inorganic anion

\section{Introduction}

From both theoretical and applied viewpoints, phase-transition compounds are popular and valuable in increasing the general understanding of structure-property relations and exploring functional materials with novel physical properties [1-10]. Phase-transition crystalline materials are usually accompanied by an abrupt change in some physical properties around the transition temperature. These materials show great applications in molecular sensors, switches, and data storage devices [11-15]. In particular, energy harvesting occurs during phase changes; thus, phase-transition materials may serve as energy-saving materials. Designing special inorganic-organic hybrid compounds with molecular dielectrics is an effective method for synthesizing ideal phase-transition materials [16-19].

Phase-transition inorganic-organic hybrid compounds display novel crystal structures and interesting physical properties, including ferroelectric, dielectric, optical, and piezoelectric properties [20-24]. Among them, 15-crown-5 or 18-crown-6 are good candidates, owing to their variable conformation, such as [( $\left.\mathrm{RNH}_{3}\right)(18$-crown-6)][A], where $\mathrm{R}$ is an alkyl or aryl group, and $\mathrm{A}$ is an anion. The driving force of these phase-transition compounds can be ascribed to the motional changes in the $\mathrm{R}-\mathrm{NH}_{3}{ }^{+}$guest cation ( $\mathrm{R}=$ aryl group) or / and anionic units. The use of the $\mathrm{R}$ group as a molecular rotor or pendulum unit produces desirable properties [25-29]. As a result, the motion of organic 
ammonium cations changes their dynamic state. This alteration further leads to dielectric changes and ferroelectricity through the phase transitions between the disordered high-temperature phase (HTP) and ordered low-temperature phase (LTP) [30-33]. On the contrary, the asymmetric unit of the supramolecular adduct also contains counter anions. These anions are primarily tetrahedral ions, such as $\mathrm{BF}_{4}{ }^{-}, \mathrm{ClO}_{4}{ }^{-}$, and $\mathrm{IO}_{4}{ }^{-}$. These anions easily change position with varied temperatures and weak interactions, because of their higher symmetry and relatively small volume [34,35]. In fact, inorganic anions (such as $\mathrm{HSO}_{4}{ }^{-}$) have rarely been explored. Given these findings, in this work we report the syntheses of (4-HNA)(18-crown-6) $\left(\mathrm{HSO}_{4}\right)(\mathbf{1})$ and (4-HNA) 2 (18-crown-6) $)_{2}\left(\mathrm{PF}_{6}\right)_{2}\left(\mathrm{CH}_{3} \mathrm{OH}\right)$ (2) to determine other suitable geometric anions that can regulate a potential phase transition. The structures, phase transitions, and dielectric properties of the two anions are revealed in Scheme 1.

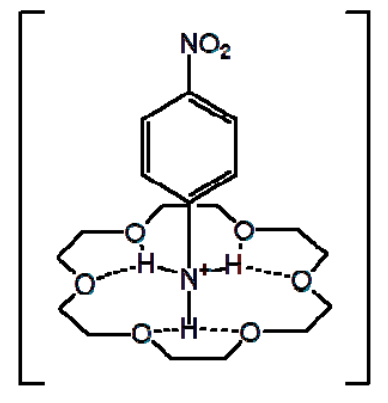

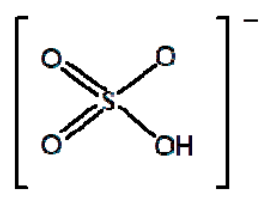

1

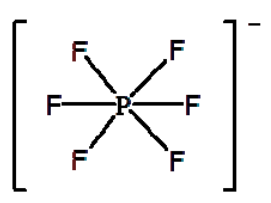

2

Scheme 1. Structural formulae of compounds 1 and 2.

\section{Results and Discussion}

\subsection{Crystal Structure of $\mathbf{1}$}

The crystal structure of $\mathbf{1}$ was characterized at different temperatures by X-ray diffraction to confirm whether the phase transition was associated with structural changes. Compound 1 crystallized in the monoclinic space group $P 2{ }_{1} /$ c with $a=10.450$ (6) $\AA, b=18.453$ (11) $\AA, c=13.466$ (8) $\AA$, $\beta=112.672(7)^{\circ}$, and $V=2396$ (2) $\AA^{3}$ in the HTP at $296 \mathrm{~K}$. At the LTP $(100 \mathrm{~K})$, crystal 1 crystallized in the monoclinic space group $P 2{ }_{1} / \mathrm{n}$ with small changes in cell parameters, i.e., $a=10.3715$ (18) $\AA$, $\mathrm{b}=18.235$ (3) $\AA, \mathrm{c}=13.384$ (3) $\AA, \beta=112.736(2)^{\circ}$, and $\mathrm{V}=2334.4$ (8) $\AA^{3}$ (Table 1).

Table 1. Crystallographic data and structural refinement details for $\mathbf{1}$ and $\mathbf{2 .}$

\begin{tabular}{|c|c|c|c|c|}
\hline & 1-LTP & 1-HTP & 2-LTP & 2-HTP \\
\hline Chemical formula & $\mathrm{C}_{18} \mathrm{H}_{32} \mathrm{~N}_{2} \mathrm{O}_{12} \mathrm{~S}$ & $\mathrm{C}_{18} \mathrm{H}_{32} \mathrm{~N}_{2} \mathrm{O}_{12} \mathrm{~S}$ & $\mathrm{C}_{37} \mathrm{H}_{68} \mathrm{~F}_{12} \mathrm{~N}_{4} \mathrm{O}_{17} \mathrm{P}_{2}$ & $\mathrm{C}_{37} \mathrm{H}_{68} \mathrm{~F}_{12} \mathrm{~N}_{4} \mathrm{O}_{17} \mathrm{P}_{2}$ \\
\hline Formula weight & 500.52 & 500.52 & 1130.88 & 1130.88 \\
\hline Temperature/K & 100 & 296 & 100 & 296 \\
\hline Crystal size $\left(\mathrm{mm}^{3}\right)$ & $0.21 \times 0.20 \times 0.19$ & $0.21 \times 0.20 \times 0.19$ & $0.316 \times 0.223 \times 0.139$ & $0.316 \times 0.223 \times 0.139$ \\
\hline Crystal system & monoclinic & monoclinic & monoclinic & monoclinic \\
\hline Space group & $P 2_{1} / \mathrm{n}$ & $P 2_{1} / \mathrm{c}$ & $P 2_{1} / \mathrm{c}$ & $P 2_{1} / \mathrm{c}$ \\
\hline a $(\AA)$ & $10.3715(18)$ & $10.450(6)$ & $10.9491(9)$ & $10.9429(9)$ \\
\hline $\mathrm{b}(\AA)$ & $18.235(3)$ & $18.453(11)$ & $23.701(2)$ & $23.687(2)$ \\
\hline c $(\AA)$ & $13.384(3)$ & $13.466(8)$ & $21.9038(16)$ & $21.8926(16)$ \\
\hline$\alpha\left({ }^{\circ}\right)$ & 90.00 & 90.00 & 90.00 & 90.00 \\
\hline$\beta\left(^{\circ}\right)$ & $112.736(2)$ & $112.672(7)$ & $113.961(4)$ & $113.962(4)$ \\
\hline$\gamma\left({ }^{\circ}\right)$ & 90.00 & 90.00 & 90.00 & 90.00 \\
\hline $\mathrm{V}(\AA 3)$ & $2334.4(8)$ & $2396(2)$ & $5194.3(7)$ & $5185.6(7)$ \\
\hline Z & 4 & 4 & 2 & 2 \\
\hline Dcalc $\left(\mathrm{g} \cdot \mathrm{cm}^{-1}\right)$ & 1.424 & 1.388 & 1.351 & 1.167 \\
\hline $\mathrm{F}(000)$ & 1064 & 1064 & 2222 & 1946 \\
\hline $\mathrm{m}\left(\mathrm{mm}^{-1}\right)$ & 0.204 & 0.198 & 0.168 & 0.112 \\
\hline Measured 2 range $\left({ }^{\circ}\right)$ & $0.999-25.01$ & $0.999-25.01$ & $0.992-24.50$ & $0.981-25.01$ \\
\hline Rint & 0.0372 & 0.0511 & 0.0992 & 0.0998 \\
\hline $\mathrm{R}(\mathrm{I}>2(\mathrm{I}))[\mathrm{a}]$ & 0.0442 & 0.0738 & 0.1820 & 0.1871 \\
\hline WR (all data) [b] & 0.1066 & 0.1608 & 0.3184 & 0.2917 \\
\hline GOF & 1.039 & 1.015 & 1.020 & 0.988 \\
\hline
\end{tabular}


The crystal structures of $\mathbf{1}$ are similar between the LTP and HTP structures. This result reveals that the asymmetric unit was composed of one cationic [(4-HNA)(18-crown-6) $]^{+}$moiety and one anionic $\mathrm{HSO}_{4}{ }^{-}$(Figure 1a). The 4-HNA cations were connected to the 18 -crown-6 ring to form a supramolecular rotator-stator structure through $\mathrm{N}-\mathrm{H} \cdots \mathrm{O}$ interactions between the $-\mathrm{NH}_{3}{ }^{+}$group and the six $\mathrm{O}\left(\mathrm{O}_{1}, \mathrm{O}_{2}, \mathrm{O}_{3}, \mathrm{O}_{4}, \mathrm{O}_{5}\right.$, and $\left.\mathrm{O}_{6}\right)$ atoms of 18-crown-6. The average hydrogen-bonding $\mathrm{N}-\mathrm{O}$ distances of 2.874 and $2.888 \AA$ at $100 \mathrm{~K}$ and $296 \mathrm{~K}$, respectively, were almost the same to those of the standard $\mathrm{NH}_{3}{ }^{+} \ldots \mathrm{O}$ distance for the crown ether molecular-based system (Table S1). The $\pi$-plane of the 4-HNA cation was nearly perpendicular to the mean plane of the oxygen atoms. The $\mathrm{N}_{1}$ atom of the 4-HNA cations was located higher than the best plane of the oxygen atoms of the crown ring, rather than in the nesting position (Figure 1a). The dihedral angles between the aromatic ring and the crown ether ring were $92.48^{\circ}(100 \mathrm{~K})$ and $93.47^{\circ}$ (296 K). In Figure $1 \mathrm{~b}$, the packing diagram of complex 1 is located along the $a+c$ axis. The packing diagram for the LTP $(100 \mathrm{~K})$ indicates that the dimer structure of the two $\mathrm{HSO}_{4}{ }^{-}$anions is linked by $\mathrm{O}-\mathrm{H} \cdots$ O hydrogen bonds that fill in the space to form four [(4-HNA)(18-crown-6)] $]^{+}$supramolecular cations. In addition, the $\mathrm{O}-\mathrm{H} \cdots$ O hydrogen-bonding interaction becomes stronger than the $\mathrm{N}-\mathrm{H}$. . O hydrogen bonds with bond distances of $2.647 \AA$ and $2.657 \AA$ at $100 \mathrm{~K}$ and $296 \mathrm{~K}$, respectively. This finding indicates that the movement of H protons was more difficult between the donor $\left(\mathrm{O}_{11}\right)$ and acceptor atoms $\left(\mathrm{O}_{10}\right)$. The most significant differences between the structures at $296 \mathrm{~K}$ and $100 \mathrm{~K}$ were the distances of the two crown ether rings. Compared with the distances at $100 \mathrm{~K}$, those at $296 \mathrm{~K}$ changed from $4.208 \AA$ to $4.063 \AA$. C-H $\cdots \pi$ interactions were noted in the $\left[(4-\mathrm{HNA})(18-\text {-crown-6) }]^{+}\right.$complex cations. The aromatic rings formed two $\mathrm{C}-\mathrm{H} \cdots \pi$ interactions with distances of $3.195 \AA$ at $100 \mathrm{~K}$ and $3.267 \AA$ at $296 \mathrm{~K}$ (Figure 2).

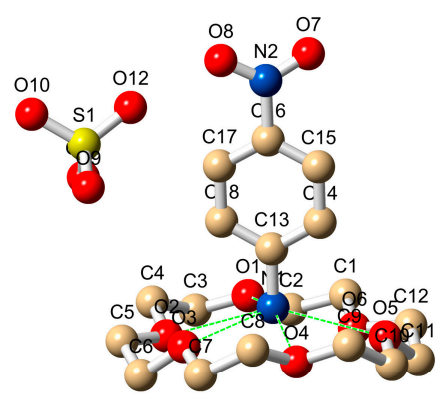

(a)

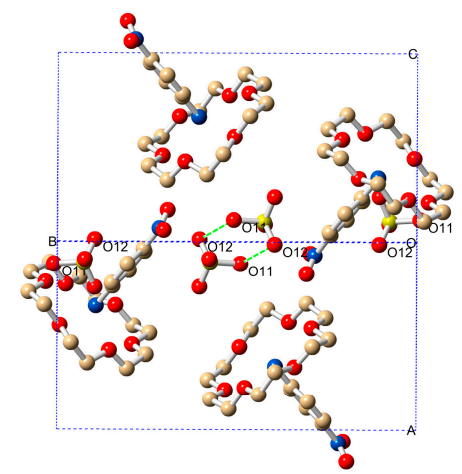

(b)

Figure 1. Crystal structure of crystal 1 at $100 \mathrm{~K}$. (a) Asymmetric unit for crystal 1, dashed lines indicate hydrogen bonds; (b) Unit cell of crystal 1 viewed along the $a+c$ axis. Most hydrogen atoms on carbon atoms are omitted for clarity.

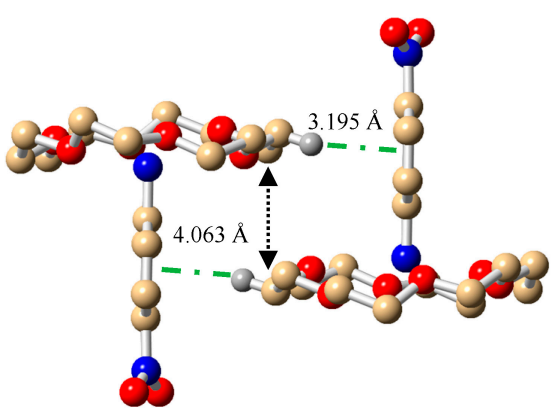

(a)

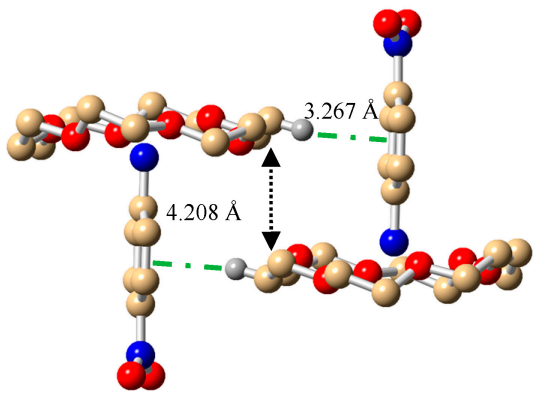

(b)

Figure 2. Arrangement of the supramolecular cations in $\mathbf{1}$ at $100 \mathrm{~K}$ (a) and $296 \mathrm{~K}$ (b) viewed in the $a+c$ plane; the dashed lines show the $\mathrm{C}-\mathrm{H} \cdots \pi$ interactions. 


\subsection{Crystal Structure of $\mathbf{2}$}

The crystal structure of 2 was analyzed in HTP (296 K) and LTP (100 K) forms. When the $\mathrm{HSO}_{4}{ }^{-}$anion was replaced with the $\mathrm{PF}_{6}{ }^{-}$anion, compound 2 at both $296 \mathrm{~K}$ and $100 \mathrm{~K}$ crystallized in the monoclinic system with the same space group $P 2{ }_{1} / \mathrm{c}$. Although the temperature changed, the space group of crystal 2 remained unchanged. Hence, no structural symmetry breaking occurred in this temperature range. Crystallographic data and details on the collection and refinement for $296 \mathrm{~K}$ and $100 \mathrm{~K}$ are listed in Table 1.

The asymmetric unit of compound 2 consisted of two independent [(4-HNA)(18-crown-6)] ${ }^{+}$ supramolecular cations, two $\mathrm{PF}_{6}{ }^{-}$anions, and one methanol molecule at $296 \mathrm{~K}$ and $100 \mathrm{~K}$ (Figure 3a). In contrast to the ordered $\mathrm{HSO}_{4}{ }^{-}$anions in 1 , the $\mathrm{PF}_{6}{ }^{-}$anions in 2 were disordered at both $100 \mathrm{~K}$ and $296 \mathrm{~K}$. The molecular structure of 2 with atomic labeling is shown in Figure 3a. The disordered $\mathrm{PF}_{6}{ }^{-}$anion and methanol molecules filled the structure between neighboring supramolecular cations (Figure 3b).

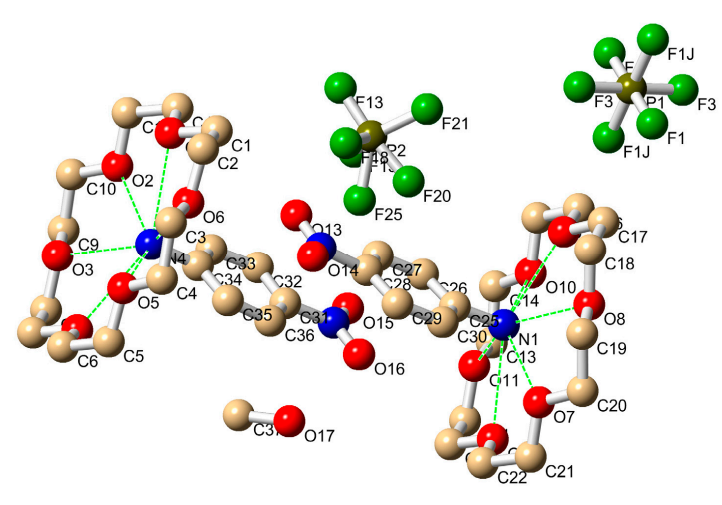

(a)

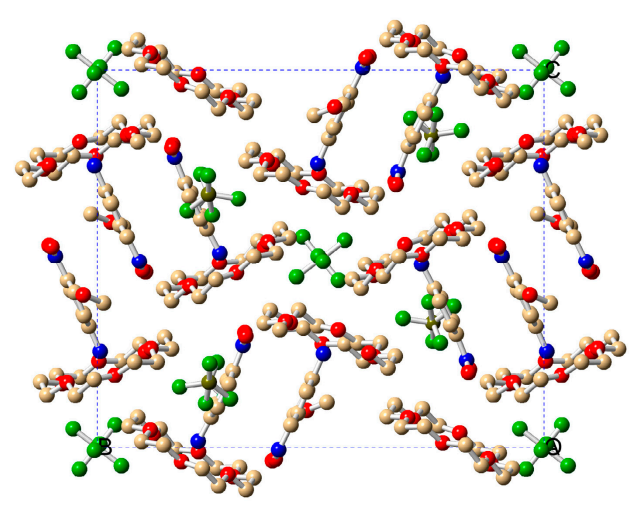

(b)

Figure 3. Asymmetric unit (a) and packing diagram (b) of crystal 2 viewing along the $a$-axis at $100 \mathrm{~K}$ and $296 \mathrm{~K}$. Most of the hydrogen atoms on the carbon atoms are omitted for clarity.

The most striking structural features in the LTP and HTP forms were the distances of the two crown ether rings. The distances of crystal 2 from the neighboring [(4-HNA)(18-crown-6)] ${ }^{+}$ supramolecular cations were $8.877 \AA$ (100 K) and $9.082 \AA$ (296 K) (Figure 4). Interestingly, it was found that obvious disorder phenomena occur in the HTP phase of the $-\mathrm{NO}_{2}$ group. The $\mathrm{O}_{14}, \mathrm{O}_{15}$, $\mathrm{O}_{16}, \mathrm{O}_{17}$ atoms of $-\mathrm{NO}_{2}$ group in supramolecular cations are distinctly disordered and occupy two sites $\left(\mathrm{O}_{14 \mathrm{~A}}, \mathrm{O}_{14 \mathrm{~B}}, \mathrm{O}_{15 \mathrm{~A}}, \mathrm{O}_{15 \mathrm{~B}}, \mathrm{O}_{16 \mathrm{~A}}, \mathrm{O}_{16 \mathrm{~B}}, \mathrm{O}_{17 \mathrm{~A}}, \mathrm{O}_{17 \mathrm{~B}}\right)$. The occupation factors of oxygen atoms of $-\mathrm{NO}_{2}$ group are displayed in Table $\mathrm{S} 2$, suggesting that biased $-\mathrm{NO}_{2}$ group orientation was achieved in compound 2 (Figure $4 \mathrm{~b}$ ). The $-\mathrm{NH}_{3}{ }^{+}$group resided in a perching position, and attained a configuration similar to that of crystal 1; the group was linked by the oxygen atoms of the crown ethers through the six $\mathrm{N}-\mathrm{H} \cdots \mathrm{O}$ hydrogen bonds. Apparent hydrogen bonding interactions occurred between the nitrogen and oxygen atoms with bond lengths of 2.821-2.956 $\AA$ and 2.816-2.966 $\AA$ at $100 \mathrm{~K}$ and $296 \mathrm{~K}$, respectively (Table S3). In crystal 2 , the distance between two adjacent crown ether rings was nearly twice as long as that in crystal 1 at $100 \mathrm{~K}$ and $296 \mathrm{~K}$ (Figure 4). In crystal 1, the dimer structure of two $\mathrm{HSO}_{4}{ }^{-}$anions occupied a larger space volume, resulting in a relatively closer packing pattern for the $\left[(4-\mathrm{HNA})(18-\text { crown-6) }]^{+}\right.$supramolecular cation. Furthermore, no $\mathrm{C}-\mathrm{H} \cdots \pi$ interactions existed in the supramolecular cations. However, weak $\pi \cdots \pi$ interactions were found between the aromatic rings of the $[(4-\mathrm{HNA})(18-\mathrm{crown}-6)]^{+}$supramolecular cations. These interactions stabilized the crystal packing and formed the alternated inorganic-organic hybrid structure in the $b c$ plane (Figure S1). 


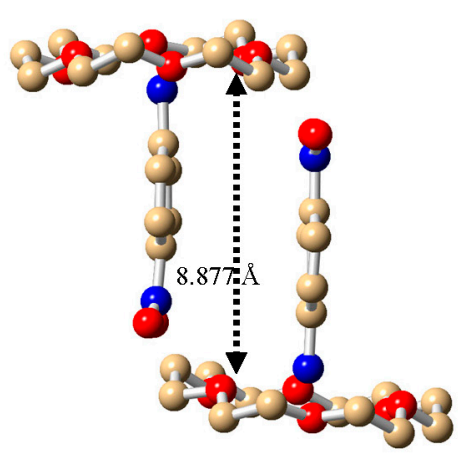

(a)

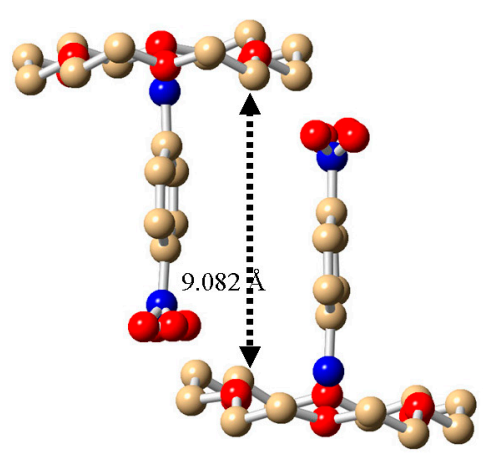

(b)

Figure 4. Arrangement of the supramolecular cations in 2 at $100 \mathrm{~K}$ (a) and $296 \mathrm{~K}(\mathbf{b})$ viewed along the $a$-axis; the dashed lines show the distance of the adjacent two crown ether rings.

\subsection{Differential Scanning Calorimetry}

Differential scanning calorimetry (DSC) is commonly used to detect whether a compound displays a phase transition triggered by temperature. This approach is also used to confirm the existence of a heat anomaly during heating and cooling. When a compound undergoes a structural phase transition with a thermal entropy change, reversible heat anomalies are detected during heating and cooling. In the DSC spectrum obtained from crystal 1, a main endothermic peak and a main exothermic peak were observed at heating of $257 \mathrm{~K}$ and cooling of $252 \mathrm{~K}$, respectively, with a $5 \mathrm{~K}$ hysteresis width (Figure 5a). These exothermic and endothermic peaks clearly reveal the occurrence of a reversible phase transition. The entropy change $(\Delta S)$ of the phase transition was too low to be estimated from the DSC. The wide heat hysteresis and peak shapes reflect the characteristics of a first-order phase transition. The driving force of the phase transition was confirmed by evaluating the crystal structure across varying temperatures. For example, apparent differences were observed for the distances of two crown ether rings, with values of $4.063 \AA$ at $100 \mathrm{~K}$ and $4.208 \AA$ at $296 \mathrm{~K}$. Additionally, the dihedral angle between the aromatic ring and the crown ring slightly changed from $92.48^{\circ}$ in the LTP form to $93.47^{\circ}$ in the HTP form.

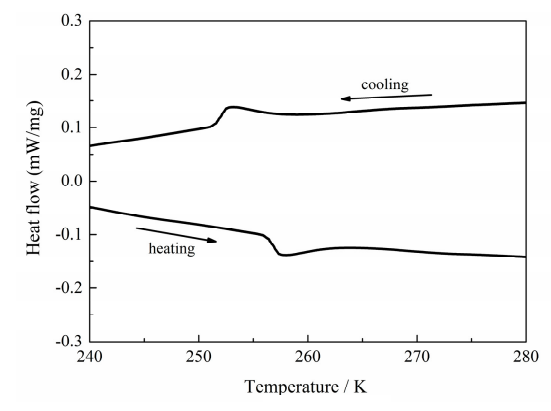

(a)

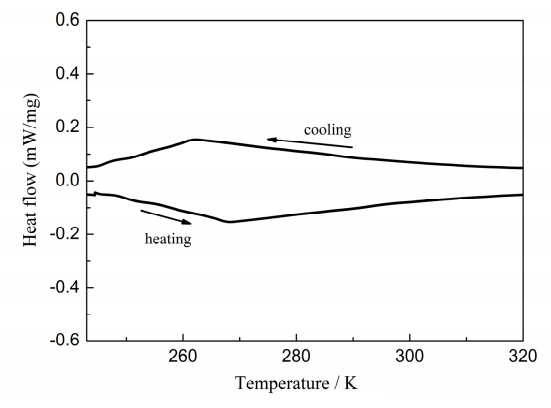

(b)

Figure 5. DSC curves of crystal 1 (a) and crystal 2 (b) in a heating-cooling cycle.

Compared with the DSC measurements for crystal 1, those for crystal 2 were conducted within the temperature range $240-320 \mathrm{~K}$, and revealed two anomalies at $266 \mathrm{~K}$ (heating) and $261 \mathrm{~K}$ (cooling) (Figure $5 b$ ). The thermal hysteresis was about $5 \mathrm{~K}$, and the entropy change $(\Delta S)$ of the phase transition was also too low to be estimated from the DSC. The almost non-existent hysteresis and small heat anomalies clearly reflect the continuous characteristic of the phase transition and thus effectively show features of a second-order phase transition. The distances of neighboring [(4-HNA)(18-crown-6)] ${ }^{+}$ supramolecular cations were $8.877 \AA$ (100 K) and $9.082 \AA$ ( $296 \mathrm{~K})$ for crystal 2. For these reasons, crystals 
1 and 2 both revealed reversible phase transitions despite containing different anions. This finding implies that the phase transition may have originated from the [(4-HNA)(18-crown-6) $]^{+}$supramolecular cations, a finding observed in similar compounds.

\subsection{Dielectric Property}

The variable-temperature dielectric response is another common method for studying phase transitions, especially at relatively high frequency ranges. This method is useful for identifying phase transitions. The temperature-dependent dielectric constant of the powder samples of crystals $\mathbf{1}$ and $\mathbf{2}$ were presented at four selected frequencies, namely, $5 \mathrm{KHz}, 10 \mathrm{KHz}, 100 \mathrm{KHz}$, and $1 \mathrm{MHz}$. Strong and significant dielectric anomalies were observed around the $T_{\mathrm{c}}$. For crystal 1 , the dielectric constant slowly increased with rising temperature below $250 \mathrm{~K}$ (Figure 6a). Interestingly, when the temperature neared $255 \mathrm{~K}$, the dielectric constant sharply increased to a maximum value of 22.5 at $5 \mathrm{KHz}$. Then, the dielectric constant abruptly decreased and achieved a minimum value of 11.91 at about $265 \mathrm{~K}$. The sharp peak-like dielectric anomaly further confirms the phase transition in 1, which is consistent with the DSC result.

For crystal 2, the dielectric constant slowly increased, with an abrupt slope at around $265 \mathrm{~K}$ during heating (Figure 6b). The maximum dielectric constant value was about 8.14 at $5 \mathrm{KHz}$; this value corresponds to a high dielectric state. The dielectric constant of 2 achieved a sudden rapid increase at room temperature. Compound 2 attained small DSC and dielectric anomalies at about $265 \mathrm{~K}$; this pattern is a feature of a second-order phase transition. The relatively weak dielectric anomaly of crystal $\mathbf{2}$ relative to that of $\mathbf{1}$ is presented in the temperature ranges. This finding is probably due to the unchanged electric polarizations of ions and molecules in the crystal lattice.

The temperature-dependent dielectric response of compound $\mathbf{1}$ and $\mathbf{2}$ both display one sharp peak-like anomaly upon heating at $255 \mathrm{~K}$ and $265 \mathrm{~K}$, respectively. However, there is no distinct dielectric anomaly for $\mathbf{1}$ and $\mathbf{2}$ upon cooling. For the cooling and heating processes, the DSC curves for the two crystals exhibit relatively weak exothermic and endothermic peaks. Phase transition occurs in compound $\mathbf{1}$ and $\mathbf{2}$, thus leading to dielectric anomalies with the increase in temperature. Because crystal $\mathbf{1}$ and $\mathbf{2}$ have undergone phase transitions of temperature variation once with the structural changes, there is no distinct dielectric response with the decrease in temperature.

The variable-temperature crystal structures of $\mathbf{1}$ and $\mathbf{2}$ reveal that the phase transition and dielectric anomaly in the same temperature range may be caused by the structural interactions and different crystal packing patterns in the LTP and HTP forms. Crystals $\mathbf{1}$ and $\mathbf{2}$ achieved significant differences at $296 \mathrm{~K}$ and $100 \mathrm{~K}$, i.e., the distances between the two adjacent crown rings of 2 were $8.877 \AA$ ( $100 \mathrm{~K})$ and $9.082 \AA(296 \mathrm{~K})$. These distances were larger than the values of $4.063 \AA$ (100 K) and $4.208 \AA$ (296 K) in 1 . This finding suggests that the inorganic anion tunes the crystal and hence affects the phase-transition points and types.

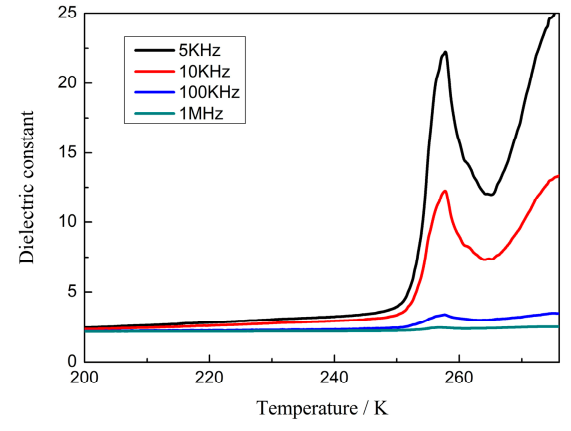

(a)

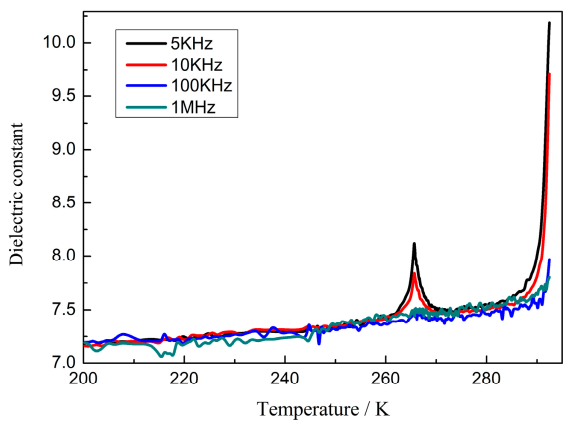

(b)

Figure 6. Dielectric properties for crystal $\mathbf{1}(\mathbf{a})$ and $\mathbf{2}(\mathbf{b})$ measured as a function of temperature under a frequency of $5 \mathrm{KHz}$ to $1 \mathrm{MHz}$. 


\section{Materials and Methods}

\subsection{Materials and Instrument}

The chemicals and solvents employed in this work were commercially obtained as chemically pure and used without any further purification. Infrared (IR) spectra were obtained using an Affinity-1 spectrophotometer and $\mathrm{KBr}$ pellets in the $4000-400 \mathrm{~cm}^{-1}$ region. Thermogravimetric analyses (TGA) were performed with a SHIMADZU DTG-60 thermal analyzer in a nitrogen atmosphere from room temperature to $800 \mathrm{~K}$ with a heating rate of $10 \mathrm{~K} / \mathrm{min}$ using aluminum crucibles (Figures S2 and S3). Elemental analyses were conducted using a Vario EL Elementar Analysensysteme GmbH at the TRW Research Collaboration Center, YanZhou, Shandong. DSC measurements were performed by heating and cooling the samples $(16 \mathrm{mg}$ ) within the temperature range $210-280 \mathrm{~K}$ on a TA Q2000 DSC instrument under nitrogen. Meanwhile, the crystal dielectric constants were measured with a TH2828 Precision LCR meter within the frequency range of $500 \mathrm{~Hz}-1 \mathrm{MHz}$, applied voltage of $1.0 \mathrm{~V}$, and temperature sweeping rate of approximately $2 \mathrm{~K} / \mathrm{min}$.

$X$-ray single crystal diffraction: X-ray diffraction experiments were conducted on crystals $\mathbf{1}$ and 2 using a Bruker CCD diffractometer with Moka radiation $(\lambda=0.71073 \AA)$ at $100 \mathrm{~K}$ and $296 \mathrm{~K}$. The structures of 1 and $\mathbf{2}$ were elucidated by direct methods and refined by the full-matrix method based on $F^{2}$ using the SHELXL 97 software package. All non-hydrogen atoms were anisotropically refined, and the positions of all hydrogen atoms were geometrically generated. CCDC:1529205 (100 K), CCDC:1529207 (296 K) for 1 and CCDC:1529231 (100 K), CCDC:1529232 (296 K) for 2 contain the supplementary crystallographic data for this paper. These data can be obtained free of charge from The Cambridge Crystallographic Data Center via www.ccdc.cam.ac.uk/data_request/cif.

\subsection{Preparation of Compound (4-HNA)(18-crown-6) $\left(\mathrm{HSO}_{4}\right)(\mathbf{1})$}

Yellow crystals 1 were obtained by evaporating an alcohol solution containing 4-nitroaniline (20 mg), $\mathrm{H}_{2} \mathrm{SO}_{4}(50 \mathrm{mg})$, and 18-crown-6 (200 mg) at room temperature for 5 days to a $52 \%$ yield (based on 4-nitroaniline). The calculated percentage compositions of $\mathrm{C}, \mathrm{H}$, and $\mathrm{N}$ for $\mathrm{C}_{18} \mathrm{H}_{32} \mathrm{~N}_{2} \mathrm{O}_{12} \mathrm{~S}$ were $43.19 \% \mathrm{C}, 6.44 \% \mathrm{H}$, and $5.60 \% \mathrm{~N}$, respectively, whereas the measured percentage compositions were $43.11 \%, 6.42 \% \mathrm{H}$, and $5.76 \% \mathrm{~N}$, respectively. The IR spectrum of the single crystal 1 is given in Figure S4.

\subsection{Preparation of Compound (4-HNA $)_{2}(18 \text {-crown-6) })_{2}\left(\mathrm{PF}_{6}\right)_{2}\left(\mathrm{CH}_{3} \mathrm{OH}\right)$ (2)}

Single crystals of 2 were prepared by slowly evaporating a mixture of $\mathrm{HPF}_{6}(50 \mathrm{mg})$, 4-nitroaniline (20 mg), and 18-crown-6 (200 mg) in methanol solution $(50 \mathrm{~mL})$. The methanol solution was allowed to stand for approximately 5 days under room temperature. The single crystals of salt 2 were colorless transparent crystals obtained at $58 \%$ yield. The calculated percentage compositions of $\mathrm{C}, \mathrm{H}$, and $\mathrm{N}$ for $\mathrm{C}_{37} \mathrm{H}_{66} \mathrm{~F}_{12} \mathrm{~N}_{4} \mathrm{O}_{17} \mathrm{P}_{2}$ were $39.37 \% \mathrm{C}, 5.89 \% \mathrm{H}$, and $4.96 \% \mathrm{~N}$, respectively, whereas the measured percentage compositions were $39.35 \% \mathrm{C}, 5.87 \% \mathrm{H}$, and $4.89 \% \mathrm{~N}$, respectively. The IR spectrum $(\mathrm{KBr})$ of the single crystal 2 is presented in Figure S5.

\section{Conclusions}

Two inorganic-organic hybrid crystals based on the [(4-HNA)(18-crown-6)] ${ }^{+}$supramolecular cation were reported in this study. Variable-temperature crystal structure analyses and thermal measurements (DSC) showed that crystals $\mathbf{1}$ and $\mathbf{2}$ exhibited similar crystal packings and underwent reversible phase transitions at $255 \mathrm{~K}$ and $265 \mathrm{~K}$, respectively. The dielectric anomalies of crystals 1 and $\mathbf{2}$ in the temperature-frequency ranges further confirmed the existence of such phase transitions. These results indicated that the phase transitions may be caused by the [(4-HNA)(18-crown-6)] ${ }^{+}$ supramolecular cations. The inorganic anions $\left(\mathrm{PF}_{6}{ }^{-}\right.$and $\left.\mathrm{HSO}_{4}{ }^{-}\right)$played an important role in the crystal packing and regulated the phase-transition points and types. 
Supplementary Materials: The following are available online at http:/ /www.mdpi.com/2073-4352/7/7/224/s1. Arrangement of the supramolecular cations of crystal 2 (Figure S1); TG data and IR spectra of crystals 1 and 2 (Figures S2-S5); Hydrogen bond geometry of crystals 1 (Table S1); The occupation factor of oxygen atoms in $-\mathrm{NO}_{2}$ group for 296K (Table S2); Hydrogen bond geometry of crystals 2 (Table S3);

Acknowledgments: The present work was supported by prophase-sustentation fund of Xinjiang Agricultural University (Contract grant number: XJAU201511).

Author Contributions: Zunqi Liu designed the method and wrote the manuscript; Yuan Chen synthesized the crystal materials. Yang Liu and Binzu Gao supported the dielectric constant and DSC measurements. Chunli Zhu analyzed the crystal data of $\mathbf{1}$ and $\mathbf{2}$. All authors have given approval the final version of the paper.

Conflicts of Interest: The authors declare no conflict of interest.

\section{References}

1. Fu, H.; Cohen, R. Polarization rotation mechanism for ultrahigh electromechanical response in single-crystal piezoelectrics. Nature 2000, 403, 281-283. [PubMed]

2. Horiuchi, S.; Tokunaga, Y.; Giovannetti, G.; Picozzi, S.; Itoh, H.; Shimano, R.; Kumai, R.; Tokura, Y. Above-roomtemperature ferroelectricity in a single-component molecular crystal. Nature 2010, 463, 789-793. [CrossRef] [PubMed]

3. Liao, W.Q.; Zhang, Y.; Hu, C.L.; Mao, J.G.; Ye, H.Y.; Li, P.F.; Huang, S.D.; Xiong, R.G. A lead-halide perovskite molecular ferroelectric semiconductor. Nat. Commun. 2015, 6, 7338-7345. [CrossRef] [PubMed]

4. Yangui, A.; Sy, M.; Li, L.; Abid, Y.; Naumov, P.; Boukheddaden, K. Rapid and robust spatiotemporal dynamics of the first-order phase transition in crystals of the organic-inorganic perovskite $\left(\mathrm{C}_{12} \mathrm{H}_{25} \mathrm{NH}_{3}\right)_{2} \mathrm{PbI}_{4}$. Sci. Rep. 2015, 5, 16634. [CrossRef] [PubMed]

5. Yangui, A.; Pillet, S.; Mlayah, A.; Lusson, A.; Bouchez, G.; Triki, S.; Abid, Y.; Boukheddaden, K. Structural phase transition causing anomalous photoluminescence behavior in perovskite $\left(\mathrm{C}_{6} \mathrm{H}_{11} \mathrm{NH}_{3}\right) 2\left[\mathrm{PbI}_{4}\right]$. J. Chem. Phys. 2015, 143, 224201. [CrossRef] [PubMed]

6. Yangui, A.; Pillet, S.; Garrot, D.; Triki, S.; Abid, Y.; Boukheddaden, K. Evidence and detailed study of a second-order phase transition in the $\left(\mathrm{C}_{6} \mathrm{H}_{11} \mathrm{NH}_{3}\right)_{2}\left[\mathrm{PbI}_{4}\right]$ organic-inorganic hybrid material. J. Appl. Phys. 2015, 117, 115503. [CrossRef]

7. Horiuchi, S.; Ishii, F.; Kumai, R.; Okimoto, Y.; Tachiban, H.; Nagaosa, N.; Tokura, Y. Ferroelectricity near room temperature in co-crystals of nonpolar organic molecules. Nat. Mater. 2005, 4, 163-166. [CrossRef] [PubMed]

8. Akutagawa, T.; Koshinaka, H.; Sato, D.; Takeda, S.; Noro, S.I.; Takahashi, H.; Kumai, R.; Tokura, Y.; Nakamura, T. Ferroelectricity and polarity control in solid-state flip-flop supramolecular rotators. Nat. Mater. 2009, 8, 342-347. [CrossRef] [PubMed]

9. Guo, P.C.; Chen, T.Y.; Ren, X.M.; Ning, W.H.; Jin, W. A low-kdielectric metal-organic-framework compound showing novel three-step dielectric relaxations originating from orientational motion of dipolar guest molecules. New J. Chem. 2014, 38, 2254-2257. [CrossRef]

10. Lv, X.H.; Liao, W.Q.; Wang, Z.X.; Li, P.F.; Mao, C.Y.; Ye, H.Y. Design and prominent dielectric properties of a layered phase transition crystal: (cyclohexylmethylammonium) ${ }_{2} \mathrm{CdCl}_{4}$. Cryst. Growth Des. 2016, 16, 3912-3916. [CrossRef]

11. Yangui, A.; Pillet, S.; Lusson, A.; Bendeif, E.E.; Triki, S.; Abid, Y.; Boukheddaden, K. Control of the white-light emission in the mixed two-dimensional hybrid perovskites $\left(\mathrm{C}_{6} \mathrm{H}_{11} \mathrm{NH}_{3}\right)_{2}$ [ $\mathrm{PbBr}_{4}$-xIx]. J. Alloy. Compd. 2017, 699, 1122-1133. [CrossRef]

12. Zhang, Y.; Ye, H.Y.; Fu, D.W.; Xiong, R.G. An order-disorder ferroelectric host-guest inclusion compound. Angew. Chem. Int. Ed. 2014, 53, 2114-2118. [CrossRef] [PubMed]

13. Ye, H.Y.; Li, S.H.; Zhang, Y.; Zhou, L.; Deng, F.; Xiong, R.G. Solid state molecular dynamic investigation of an inclusion ferroelectric:[(2,6-diisopropylanilinium)([18]crown-6)]BF 4 . J. Am. Chem. Soc. 2014, 136, 10033-10040. [CrossRef] [PubMed]

14. Mei, G.Q.; Liao, W.Q. Structural phase transitions coupled with prominent dielectric anomalies and dielectric relaxation in a one-dimensional organic-inorganic hybrid compound $\left[\left(\mathrm{C}_{3} \mathrm{H}_{4} \mathrm{NS}\right)\left[\mathrm{CdCl}_{3}\right]\right.$. J. Mater. Chem. C 2015, 3, 8535-8541. [CrossRef]

15. Liu, Z.Q.; Kubo, K.; Noro, S.I.; Akutagawa, T.; Nakamura, T. Design of crystalline spaces for molecular rotation in crystals. Cryst. Growth Des. 2014, 14, 537-543. [CrossRef]

16. Chen, C.H.; Mu, R.; Zhang, L.; Xu, G.C. Synthesis, crystal structure and disorder-order phase transition of a new diamine template metal sulfate, $\left(\mathrm{C}_{3} \mathrm{H}_{12} \mathrm{~N}_{2}\right)_{2}\left[\mathrm{Cu}\left(\mathrm{H}_{2} \mathrm{O}\right)_{4}\left(\mathrm{SO}_{4}\right)_{2}\right]\left(\mathrm{HSO}_{4}\right)_{2}$. CrystEngComm 2016, 18, 2719-2724. [CrossRef] 
17. Tang, Y.Z.; Yu, Y.M.; Xiong, J.B.; Tan, Y.H.; Wen, H.R. Unusual high-temperature reversible phase-transition behavior, structure, and dielectric-ferroelectric properties of two new crown ether clathrates. J. Am. Chem. Soc. 2015, 137, 13345-13351. [CrossRef] [PubMed]

18. Sato, D.; Akutagawa, T.; Takeda, S.; Noro, S.I.; Nakamura, T. Supramolecular rotor: Adamantylammonium ([18]crown-6) in [Ni(dmit $\left.)_{2}\right]^{-}$salt. Inorg. Chem. 2007, 46, 363-365. [CrossRef] [PubMed]

19. Jin, Y.; Yu, C.; Wang, Y.; Li, S.; Zhang, W. Synthesis and structural phase transitions of Copper(II) and Iron(III) complexes containing $\left[\left(\mathrm{C}_{8} \mathrm{H}_{12} \mathrm{NO}\right)(18-\text {-crown-6) }]^{+}\right.$supramolecular cations. Z. Anorg. Allg. Chem. 2014, 640, 1499-1505. [CrossRef]

20. Yu, H.Y.; Ge, J.Z.; Tang, Y.Y.; Li, P.F.; Zhang, Y.; You, Y.M.; Xiong, R.G. Molecular ferroelectric with most equivalent polarization directions induced by the plastic phase transition. J. Am. Chem. Soc. 2016, 138, 13175-13178.

21. Zhang, Y.; Zhang, W.; Li, S.H.; Ye, Q.; Cai, H.L.; Deng, F.; Xiong, R.G.; Huang, S.D. Ferroelectricity induced by ordering of twisting motion in a molecular rotor. J. Am. Chem. Soc. 2012, 134, 11044-11049. [CrossRef] [PubMed]

22. Ye, H.Y.; Cai, H.L.; Ge, J.-Z.; Xiong, R.-G. Reversible structural phase transition of pyridinium-4-carboxylic acid perchlorate. J. Appl. Cryst. 2010, 43, 1031-1035. [CrossRef]

23. Wang, W.-X.; Fu, X.Q. Reversible phase transition of 4-ethoxybenzenammonium iodide. Z. Anorg. Allg. Chem. 2013, 639, 471-474. [CrossRef]

24. Nishihara, S.; Akutagawa, T.; Hasegawa, T.; Fujiyama, S.; Nakamura, T.; Nakamura, T. Two polymorphs of (anilinium)(18-crown-6)[Ni(dmit) 2 ]: Structure and magnetic properties. J. Solid State Chem. 2002, 168, 661-667. [CrossRef]

25. Zhang, S.Y.; Li, J.; Zhang, Y.; Wen, H.R.; Du, Z.-Y. Hydrogen-bond-directed assemblies of [La(18-crown-6)( $\left.\left.\mathrm{H}_{2} \mathrm{O}\right)_{4}\right]\left(\mathrm{BiCl}_{6}\right)_{3} \mathrm{H}_{2} \mathrm{O}$ and $\left[\mathrm{Nd}\left(18\right.\right.$-crown-6) $\left.\left(\mathrm{H}_{2} \mathrm{O}\right)_{4}\right]\left(\mathrm{BiCl}_{6}\right)_{3.5} \mathrm{H}_{2} \mathrm{O}$ regulated by different symmetries. J. Mol. Struct. 2016, 1125, 227-233. [CrossRef]

26. Akutagawa, T.; Shitagami, K.; Nishihara, S.; Takeda, S.; Hasegawa, T.; Nakamura, T.; Hosokoshi, Y.; Inoue, K.; Ikeuchi, S.; Miyazaki, Y.; et al. Molecular rotor of $\mathrm{Cs}_{2}\left([18]\right.$ crown-6) ${ }_{3}$ in the solid state coupled with the magnetism of [Ni(dmit) $)_{2}$ ]. J. Am. Chem. Soc. 2005, 127, 4397-4402. [CrossRef] [PubMed]

27. Wang, W.X.; Zhu, R.Q.; Fu, X.Q.; Zhang, W. Crystal structure and dielectric property of $\left(\mathrm{p}-\mathrm{CH}_{3} \mathrm{OC}_{6} \mathrm{H}_{4} \mathrm{NH}_{3}\right)^{+}\left(18-\right.$ crown-6) $\mathrm{H}_{2} \mathrm{PO}_{4}{ }^{-} \cdot 2 \mathrm{H}_{3} \mathrm{PO}_{4}$. Z. Anorg. Allg. Chem. 2012, 638, 1123-1126. [CrossRef]

28. Liu, Z.Q.; Liu, Y.; Wang, J.F.; Yang, G.F. A novel proton transfer supramolecular compound induced by $\mathrm{N}-\mathrm{H} \cdots \mathrm{O}$ hydrogen bond through 18-crown-6: Syntheses, structure, and dielectric properties. Inorg. Chem. Commun. 2015, 61, 109-112. [CrossRef]

29. Han, X.-B.; Hu, P.; Shi, C.; Zhang, W. Structure phase transition and dielectric transitions in a 1,4-diazabicyclo[2,2,2] octane (dabco) based organic crystal. J. Mol. Struct. 2017, 1127, 372-376. [CrossRef]

30. Shi, P.P.; Ye, Q.; Li, Q.; Wang, H.T.; Fu, D.W.; Zhang, Y.; Xiong, R.G. Crystal structures, phase transitions, and switchable dielectric behaviors: Comparison of a series of N-heterocyclic ammonium perchlorates. Dalton Trans. 2015, 44, 8221-8231. [CrossRef] [PubMed]

31. Wang, D.Y.; Qin, L.L.; Hou, X.L.; Ye, H.Y. Temperature-triggered phase transition in pyridazine hexafluorophosphate. Chin. Chem. Lett. 2015, 26, 145-148. [CrossRef]

32. Liu, Z.Q.; Liu, Y.; Chen, Y.; Zhao, W.Q.; Fang, W.N. Synthesis, characterization, and phase transition of an inorganic-organic hybrid compound, [(3-nitroanilinium $\left.{ }^{+}\right)\left(18-\right.$ crown-6)][$\left[\mathrm{IO}_{4}^{-}\right]\left(\mathrm{CH}_{3} \mathrm{OH}\right)$. Chin. Chem. Lett. 2017, 28, 297-301. [CrossRef]

33. Wang, H.-T.; Li, Q.; Shi, P.-P.; Zhou, L.; Zhang, Y.; Ye, Q.; Fu, D.-W. The structures and dielectric properties of high temperature phase transition compounds with 4-(dimethylamino)(pyridinium). Inorg. Chem. Commun. 2015, 62, 85-90. [CrossRef]

34. Ye, Q.; Akutagawa, T.; Ye, H.Y.; Hang, T.; Ge, J.Z.; Xiong, R.G.; Noro, S.I.; Nakamura, T. Two novel coordination polymers constructed from 2,2'-bipyridine-3,3'-dicarboxylic acid 1,1'-dioxide ligands. CrystEngComm 2011, 13, 6185-6191. [CrossRef]

35. Ye, Q.; Shi, P.P.; Chen, Z.Q.; Akutagawa, T.; Noro, S.I.; Nakamura, T. Flexible cis-cyclohexane-1,4-diammonium ion in magnetic [Ni(dmit) $)_{2}$ crystals. Eur. J. Inorg. Chem. 2012, 23, 3732-3739. [CrossRef]

(C) 2017 by the authors. Licensee MDPI, Basel, Switzerland. This article is an open access article distributed under the terms and conditions of the Creative Commons Attribution (CC BY) license (http:// creativecommons.org/licenses/by/4.0/). 